\title{
INTERSEKSI HAK ASASI MANUSIA DAN SHARI'AAH DI INDONESIA
}

\author{
Syamsul Arifin \\ Universitas Muhammadiyah Malang, Indonesia \\ E-mail: syamsarifin@umm.ac.id
}

Nafik Muthohirin

Universitas Muhammadiyah Malang, Indonesia

E-mail: nafi_m@yahoo.co.id
Tongat
Universitas Muhammadiyah Malang, Indonesia
Email: tongat_umm@yahoo.co.id

Wahyudi

Universitas Muhammadiyah Malang, Indonesia

Email: wawahyudi@yahoo.com

\begin{abstract}
This article attempts to uncover the point of encounter of human rights and sharīah in Indonesia which often contradict with each other in light of differences in its development base, both as a concept and, furthermore, as an instrument, which ultimately leads to the human dimension. The basis of the development in question is that human rights derived from human rationality, while shari's ah comes from revelation. Therefore, this article seeks to explore the compatibility between the two. Human rights and shari'ah always have a point of encounter because in principle they are both fighting for humanity. The intersection between the two is often the case- and it becomes common, because the basis for the development of the law originates from different sources. Human rights comes from human rationality, while sharíah departs from Allah's revelation. Thus, it is only natural that various debates arise as in general a discourse of knowledge. It's just that it needs to be understood that the conflict and tension that arise, should not lead to violence. On the one hand, Muslim groups who reject the principles of human rights are undoubtedly existent. However, on the other hand, many Muslims also graciously accept human rights. Accommodative people hold
\end{abstract}


the view that they have a common vision of justice, peace, equality and tolerance. Human rights need not be viewed as contradictory to Islam, in part because many Muslimmajority countries recognize and ratify human rights instruments issued by the United Nations.

Keywords: Intersection; human rights; shari`ah.

\section{Pendahuluan}

Artikel ini ingin menemukan titik perjumpaan diskursus hak asasi manusia (HAM) dan sharíah di Indonesia yang kerap dipertentangkan mengingat wujud perbedaan pada basis pengembangannya, baik sebagai suatu konsep, dan lebih jauh lagi, sebagai suatu instrumen, yang sebenarnya bermuara pada dimensi kemanusiaan. Basis pengembangan yang dimaksud adalah, HAM bersumber dari rasionalitas manusia, sementara sharī'ah bersumber dari wahyu. Sebab itu, kertas kerja ini secara lebih jauh ingin menjelajahi kompatibilitas di antara keduanya. Tentu saja, kaca pandang yang ingin dibangun tidak dalam rangka menjatuhkan satu sama lain, tetapi justru ingin menjunjung tinggi asas perlindungan, penghormatan, dan penghargaan terhadap nilai-nilai kemanusiaan itu sendiri, sehingga pembahasan di dalamnya juga jauh dari kecenderungan berpihak kepada salah satunya. Pada akhirnya, artikel ini akan membuka ruang dialog yang lebih terbuka bagi praktik hukum Islam yang seringkali dituduh melanggar HAM, dan sebaliknya HAM internasional yang dikatakan secara sepihak sebagai alat penjajahan gaya baru yang diproklamirkan negara-negara Barat. Oleh kelompok Muslim tertentu, HAM dianggap sebagai produk pemikiran Barat, sehingga tidak cocok diaplikasikan pada bangsa-bangsa Timur-tak terkecuali bagi bangsa Indonesia—yang kebudayaan masyarakatnya didasari pada nilai-nilai ketuhanan. ${ }^{1}$ Akibatnya, tak jarang bila para pegiat HAM sering disebut sebagai pemikir liberal, ${ }^{2}$ bahkan antek Barat, meskipun sesungguhnya ini masih sangat bisa diperdebatkan.

Stereotip yang demikian adanya semakin menggeliat tatkala muncul peristiwa seperti pernikahan beda agama, kekerasan terhadap pelaku LGBT (Lesbian, Gay, Biseksusal dan Transgender), dan

1 Lihat dalam Muhammad Hafiz, "Dinamika Hukum dan Hak Asasi Manusia di Negara-negara Muslim”, Jurnal al-Abkam, Vol. 23 No. 2 (2013), 201-224.

2 Untuk keterangan mengenai hal ini, salah satu contohnya dapat dibaca misalnya dalam artikel di laman berikut: https://www.nahimunkar.org/komnas-hamkembali-dikuasai-kaum-liberal/ 
kelompok minoritas keagamaan (Shī'ah, Ahmadiyah dan agama-agama lokal), serta ketika momentum pergantian komisioner Komisi Nasional Hak Asasi Manusia (Komnas HAM). Ironisnya, seringkali ketegangan-ketegangan yang ditimbulkan akibat streotip ini diperparah dengan keluarnya fatwa Majelis Ulama Indonesia (MUI), seperti halnya pada kasus pengusiran kelompok Shī'ah di Sampang, Madura pada tahun 2012.

Berkaca dari beberapa peristiwa yang pernah terjadi, ketika mencuat pelanggaran HAM yang bersentuhan dengan kelompok keagamaan di negeri ini, hampir selalu direspons secara berlebihan. Untuk beberapa kasus, tidak jarang berujung pada tindakan anarki. Kejadian yang masih hangat (Juni 2017), misalnya, terjadi pada Fiera Lovita, seorang dokter di RSUD Solok, Sumatera Barat, yang mengalami aksi persekusi oleh Front Pembela Islam (FPI) karena dianggap menghina pemimpinnya, Rizieq Syihab atas kasus konten porno dengan seorang perempuan bernama Firza melalui statusnya di Facebook.

Dengan melimpahnya rujukan yang mendiskusikan HAM dan sharī'ah, tampak diskursus ini menarik minat para peneliti, baik dari dalam maupun luar negeri, terlebih karena dari setiap isu yang berkembang acapkali membentuk dua kutub yang saling berseberangan. Dalam upaya perlindungan kelompok minoritas agama, misalnya, para aktivis HAM mendesak supaya pemerintah bertindak cepat dalam memberikan perlindungan hukum. Namun, sebagian umat Islam justru menghendaki yang sebaliknya. Bagi mereka, pemerintah harus bertindak tegas untuk tidak mengakui keberadaan mereka.

Iklim demokrasi yang semakin terbuka seperti sekarang-yang juga diakibatkan inkonsistensi pemerintah menjalankan hak asasi manusia-tampaknya, pro dan kontra dalam menanggapi berbagai masalah yang bersentuhan dengan prinsip HAM dan Hukum Islam akan terus dijumpai. Dari dulu hingga kini kenyataan ini mengemuka karena kerap muncul pandangan yang menjelaskan HAM internasional tidak kompatibel dengan prinsip-prinsip hukum Islam. Perspektif yang mengambil jarak di antara keduanya ini melekat pada kelompok Muslim yang mendasarkan cara berpikirnya pada perilaku ekslusif. Bahkan, dengan mengatakan bahwa HAM dibuat oleh bangsa-bangsa Barat sehingga tidak ada kesesuain dengan doktrin Islam. 
Pasca-reformasi dan setelah kran demokrasi dibuka secara lebarlebar, keberadaan kelompok Muslim yang masuk pada kategori ini semakin tumbuh subur. Mereka bersuara kencang melebihi para aktivis dan pembela HAM. Akibat fakta yang sedemikian rupa, tidak mengherankan bila persingunggan HAM dan sharíah dalam merespons berbagai problem kekinian hampir selalu menemui kebuntuan.

Sejujurnya, kemunculan Muslim eksklusif tersebut bukan satusatunya faktor penanda bagi dimulainya persentuhan HAM dan shari`ah di Indonesia pasca-Orde Baru. Dalam melihat persentuhan keduanya, Arskal Salim dan Azyumardi Azra paling tidak merujuk pada empat perkembangan penting, yang dipandang memiliki konsekuensi besar terhadap penegakan hukum HAM, yaitu: Pertama, perubahan ideologi Partai Persatuan Pembangunan (PPP) dan Partai Bulan Bintang (PBB) dari Pancasila menjadi Islam; Kedua, terjadinya peningkatan tuntutan peraturan daerah (perda) sharīah di beberapa daerah; Ketiga, munculnya sejumlah kelompok garis keras Islam (bardliners) seperti Front Pembela Islam, Majelis Mujahidin Indonesia (MMI), Laskar Jihad dan Hizbut Tahrir Indonesia (HTI); Keempat, meningkatnya popularitas majalah/penerbitan Islam yang saat itu diwakili oleh Sabili, majalah mingguan yang dicetak sebanyak 100 ribu eksemplar setiap edisinya saat itu. ${ }^{3}$

Keempat faktor yang disebutkan Arskal Salim dan Azyumardi Azra tersebut berkontribusi pada pengerasan pemahaman keagamaan umat Islam, yang pada akhirnya memperteguh keberadaan kelompok Muslim garis keras. Dampaknya, berbagai aksi kekerasan yang dimotori kelompok Muslim garis keras terjadi secara berulang. FPI menyerang Aliansi Kebangsaan untuk Kebebasan Beragama dan Berkeyakinan (AKBB) karena menyuarakan pembelaan terhadap jemaah Ahmadiyah (2008), warga Cikeusik dan beberapa orang dari sekitar Bogor menyerang dan menewaskan 3 jemaah Ahmadiyah, serta menghancurkan rumah ibadah mereka (2011), dan pengusiran oleh kelompok yang mengatasnamakan diri sebagai Sunni terhadap pengikut Syiah di Sampang, Madura (2012).

\footnotetext{
3 Penjelasan mengenai hal ini dapat dibaca lebih lengkap dalam, Syamsul Arifin, Attitudes to Human Rights and Freedom of Religion or Belief in Indonesia: Voices of Islamic Religious Leaders in East Java (Yogyakarta: Kanisius, 2010), 11-13. Dikutip dari Arskal Salim dan Azyumardi Azra, "Introduction: The State and Shari'a in The Perspective of Indonesia Legal Politics”, dalam Azyumardi Azra dan Arskal Salim (eds.), Shariah and Politics in Modern Indonesia (Singapore: Institute of Southeast Asian Studies, 2003).
} 
Sementara di pihak lain, respons pemerintah dalam mengupayapakan penegakan dan perlindungan hukum bagi korban pelanggaran HAM, seperti yang tersebut di atas, terkesan lambat dan tidak tegas. Hal ini tampak dari pemberian hukuman bagi pelaku kekerasan dan perusakan rumah ibadah di Cikeusik yang hanya mendapatkan tiga bulan kurungan penjara. ${ }^{4}$ Tidak mengherankan bila semenjak Orde Baru tumbang (1998) hingga sekarang, tepatnya 19 tahun lamanya, ancaman dan kekerasan bersentimen HAM terus berlangsung dengan mengatasnamakan agama.

Pemerintah tidak bisa bersikap tegas dengan menjalankan secara penuh konsep HAM Universal yang disetujui oleh banyak negara itu karena mayoritas penduduk Indonesia beragama Islam, yang sudut pandang berpikirnya masih banyak yang menolak segala hal yang merupakan produk dari pemikiran Barat. Selain itu, dalam kasus pembelaan kelompok minoritas, negara juga sering tidak hadir karena harus berseberangan pendapat dengan kelompok Muslim bersudut pandang kaku dalam memahami HAM. Sekali lagi, karena kelompok garis keras ini beranggapan bahwa konsep HAM Internasional bertentangan dengan shari'ah. HAM dipandang sebagai alat hegemoni pemikiran yang akan merusak sistem kebudayaan umat Islam.

Bukan hal yang mustahil bila laporan Setara Institute mengenai Tindak Intoleransi Beragama dan Berkeyakinan setiap tahunnya mengalami peningkatan. Pada 2016, Setara Institute mencatat sebanyak 208 peristiwa kekerasan beragama dan berkeyakinan, yang dibarengi 270 tindakan. Penggunaan cara-cara intoleransi yang sedemikian mengerikan memperjelas hubungan yang tidak harmonis antara Islam dengan HAM. Apalagi, pelaku kekerasan tersebut tidak lain berasal dari sebagian orang Islam yang mengatasnamakan diri sebagai para pembela agama Tuhan. Jelas saja, kenyataan ini merubah citra Islam yang sebenarnya penuh dengan kedamaian, keramahtamahan, dan toleran menjadi sesak dengan propaganda kebencian, permusuhan, dan tindakan anarki.

Padahal, dalam berbagai kajian HAM, disebutkan bahwa tindakan yang dimotori oleh negara maupun masyarakat yang memiliki tujuan

\footnotetext{
${ }^{4}$ Ketidaktegasan pemerintah terhadap pelanggaran HAM tercermin pada beberapa kasus lainnya, seperti kebijakan hukuman mati, perkawinan sejenis (Lesbian, Gay, Biseksual dan Transgender/ LGBT), menikah beda agama, dan penghilangan nyawa terhadap sejumlah aktivis. Dalam beberapa isu sensitif ini, pemerintah tidak berani ambil sikap pro terhadap HAM. Meski mendapat kecaman dari banyak aktivis dan pembela HAM, namun negara tetap cuek bebek atas persoalan-persoalan ini.
} 
untuk mengancam atau menyerang kelompok yang berbeda agama dan kepercayaan disebut sebagai salah satu bentuk persekusi, ${ }^{5}$ sehingga sangat jelas perilaku ini bertolak belakang dengan prinsipprinsip HAM. Jika mau intropeksi, sesungguhnya Islam justru mengajarkan sebaliknya, yaitu memuliakan dan memberikan penghargaan terhadap nilai-nilai kemanusiaan. Misalnya, teks yang menyebutkan supaya umat Muslim berlaku adil (al-Māidah: 8-10), peduli terhadap sesama (al-Māūun: 1-7), larangan saling bermusuhan (al-Hujurāt: 12), serta merajut kebersamaan (al-Ḥujurāt: 10), sangat ditekankan. ${ }^{6}$

Ayat-ayat al-Qur'ān, yang sangat prinsipil itu, menyimpan begitu banyak ajaran pemuliaan dan pemerdekaan terhadap manusia. ${ }^{7}$ Bahkan, pada konteks kenabian Muhammad, tujuan utamanya juga bermaksud melakukan pembebasan dan pemuliaan hak dasar manusia sebagai makhluk ciptaan Tuhan. Imam al-Shātibī, dalam memandang prinsip dasar kemanusiaan, menyebut hal tersebut sebagai kemaslahatan yang primer (al-darüriyat). ${ }^{8}$ Kemaslahatan primer itu

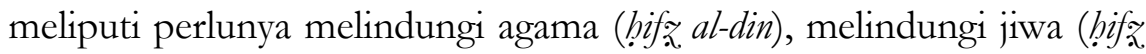

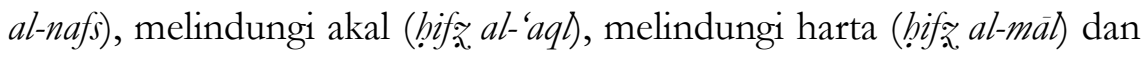
melindungi keturunan (bifzal-nafs). Dengan begitu, konsep dasar Islam sesungguhnya lebih dari ajaran tentang ketauhidan (transenden), tetapi menganjurkan setiap manusia untuk menghargai keberagaman, menghormati jiwa, memuliakan kebebasan berpikir, serta menjamin hak hidup yang layak bagi seluruh manusia. Doktrin "kemaslahatan

5 Lihat S.M. Eltayeb, "A Human Rights Framework for Defining and Understanding Intra-Religious Persecution in Muslim Countries", dalam Nazila Ghanea (ed.), The Challenge of Religious Discrimination at the Dawn of the Millenium (Leiden: Martinus Nijhoff Publisher, 2003), 83-91.

${ }^{6}$ Untuk mendapatkan gambaran cukup lengkap tentang doktrin-doktrin Islam yang mengajarkan strategi perdamaian bisa dibaca selengkapnya dalam Mohammed AbuNimer, Nonviolance and Peace Building in Islam: Theory and Practice (Florida, University Press of Florida: 2003). Sekadar informasi bahwa Abu-Nimer adalah senior adviser di sebuah lembaga internasional yang berkomitmen mempromosikan perdamaian, dialog agama-agama, dan memberikan pendidikan dan pemahaman kepada para pemimpin muda di berbagai negara tentang agama dan perdamaian, KAICIID (King Abdullah bin Abdulaziz International Centre for Interreligious and Intercultural Dialogue).

7 Untuk hal ini, baca dalam Kuntowijoyo, Paradigma Islam: Intrepretasi untuk. Aksi (Jakarta: Mizan, 1991).

${ }^{8}$ Lihat dalam Abū Ishạāq al-Shātịī, al-Muwāaaqāt fì Usūl al-Sharīah, Vol. 2 (Beirut: Dār al-Kutub al- 'Ilmīyah: t.th.), 3-23. 
primer", yang pada akhirnya menempatkan Islam lebih dari sekadar agama, tapi peradaban yang sempurna.

Sementara HAM internasional (modern), sejarah berdirinya diinisiasi oleh tanggungjawab negara para pemenang Perang Dunia II (1939-1945) untuk mengembalikan kehidupan manusia secara global pasca era kehancuran. Sebab, pasca-perang, kehidupan manusia masih dihantui dengan perasaan takut, ancaman terjadinya perang secara berulang, kelaparan, kemiskinan, pembunuhan, serta berbagai bentuk tindakan dehumanisasi lainnya, sehingga menuntut sejumlah negara seperti Inggris, Amerika Serikat dan Prancis (Blok Sekutu) serta Uni Soviet dan Tiongkok (Blok Poros) untuk mengembalikan perdamaian dunia. Konsensus baru mengenai HAM itu disepakati melalui Declaration of Human Rights (DUHAM) pada 1948. ${ }^{9}$ Dari perkembangan hukum dan kelembagaan inilah kemudian terbangun landasan konseptual dan kelembagaan hak asasi manusia internasional kontemporer. ${ }^{10}$

Dalam meratifikasi HAM, sejujurnya Indonesia dapat dikatakan lebih maju dibanding negara-negara lain di Asia Tenggara (kecuali dengan Filipina). Hingga saat ini, negara yang mayoritas penduduknya beragama Islam tersebut telah meratifikasi delapan konvensi internasional. ${ }^{11}$ Namun sejak 2005, upaya ratifikasi terhadap berbagai

\footnotetext{
9 Beberapa hal yang tertera dalam DUHAM, yaitu: (1) Setiap manusia memilik hak untuk hidup bebas dan mendapatkan perlindungan; (2) hak untuk diakui kepribadiannya menurut hukum (3) hak mendapatkan jaminan hukum dalam perkara pidana; (4) hak untuk masuk dan keluar wilayah suatu negara; (5) hak mendapat hak milik atas benda; (6) hak untuk bebas mengutarakan pikiran dan perasaan; (7) hak untuk bebas memeluk agama; (8) hak untuk bebas mendapatkan pekerjaan; dan (9) dan hak untuk berdagang.

${ }^{10}$ Lihat dalam Knut D. Asplund, Suparman Marzuki, dan Eko Riyadi (eds.), Hukum Hak Asasi Manusia (Yogyakarta, PUSHAM UII: 2008), 34. Mengenai sejarah HAM dalam perspektif kritis, dapat juga dibaca dalam Sumner B. Twiss, "History, Human Rights and Globalization", The Journal of Religious Ethics, Vol. 32, No. 1 (Spring, 2004), 39-70.

${ }^{11}$ Dari 50 instrumen internasional yang dikeluarkan PBB, hanya delapan instrumen yang diratifikasi Indonesia, yaitu: 1) Konvensi Hak Politik Perempuan (UU No. 68 tahun 1958); 2) Konvensi Penghapusan segala Bentuk Diskriminasi terhadap Perempuan (UU No.7 Tahun 1984); 3) Konvensi menentang Apatheid dalam Bidang Olah Raga (1958); 4) Konvensi mengenai Hak Anak (Kepres No.36 tahun 1990); 5) Konvensi Menentang Penyiksaan dan Perlakuan atau Hukuman Lainnya yang Kejam, Tidak Manusiawi atau Merendahkan Martabat Manusia (UU No.5 tahun 1998); 6) Konvensi Penghapusan Segala Bentuk Diskriminasi Rasial (UU No.29 tahun 1999); 7) Sejumlah Konvensi ILO (mengenai perburuan); 8)
} 
instrumen HAM internasional lainnya tidak berjalan lagi meski telah didesak oleh para aktivis HAM. Yang lebih parah, meskipun cukup maju dalam ratifikasi, pada praktiknya pemerintah acapkali tidak tegas dalam implementasinya. ${ }^{12}$

Padahal, sebagai negara tetap anggota PBB, harusnya Indonesia menjalankannya secara maksimal. Kenyataan ini salah satu faktornya karena ketidakberanian pemerintah untuk mengambil kebijakan yang tidak populis dengan mempraktikan prinsip-prinsip HAM secara utuh. Sebab, tampaknya, pemerintah lebih melihat pada sisi kepentingan politik dibanding benar-benar memperjuangkan suara kemanusiaan. Problem ini dapat disaksikan secara kasat mata, misalnya, sebanyak 81 kepala keluarga yang terdiri dari 335 jiwa pemeluk Shī'ah Sampang (Madura) yang terusir lima tahun lalu dari kampung halamannya masih bertempat tinggal di rumah susun Jemundo Sukodono (Sidoarjo). Kondisi kehidupan mereka kian memprihatinkan: tidak bekerja, hidup mengandalkan santunan, serta anak-anak tidak bersekolah.

Sebagai sebuah negara besar, yang mayoritas penduduknya beragama Islam, Indonesia sepatutnya menjadi teladan bagi praktik "hubungan baik" antara HAM dan shari'ah di sejumlah negara Islam lainnya. Apalagi dengan melihat situasi di sejumlah negara di Timur Tengah sekarang yang dipenuhi dengan kekacuan, sangat tidak mungkin penerapan HAM di negara seperti Tunisia, Irak, Libya, bahkan Arab Saudi bisa diharapkan menjadi lebih baik. Dengan artian bahwa negara-negara tersebut dapat memberikan penghargaan, perlindungan, dan penghormatan terhadap perempuan, aktivis, bahkan anak-anak. Pada tataran ini, umat Islam perlu berpikir secara terbuka dengan memahami doktrin keagamaannya secara progresif. Hal ini bertujuan untuk melihat sisi baik bahwa hukum Islam dan HAM memiliki kompatibitas yang sama-sama memperjuangan nilai kemanusiaan.

Konvenan Internasional tentang Hak-hak Sipil dan Politik (UU Nomor. 12 tahun 2005).

12 Mengenai praktik ratifikasi HAM oleh Indonesia, baca dalam Debora Aprilany Grace Rompis, "Praktik Ratifikasi terhadap Perjanjian Internasional Hak Asasi Manusia di Indonesia", Jurnal ex Crimen, Vol. 6, No. 4 (Juni, 2017), 135-144. 


\section{Persinggungan HAM dan Sharī'ah}

Perdebatan klasik antara HAM dan Hukum Islam seolah tidak ada habisnya. ${ }^{13}$ Masing-masing memiliki argumentasi yang sama kuat hingga memunculkan dua kubu arus utama, yaitu yang menolak (antagonis) dan yang menerima HAM Universal (akomodatif/negosiatif). ${ }^{14}$ Bagi kelompok antagonis, mereka dipenuhi dengan kecurigaan terhadap negara-negara pengusul (khususnya Barat) karena hak asasi manusia dianggap akan menjadi pintu masuk yang akan merusak kebudayaan bangsa-bangsa Timur. Sementara kubu akomadatif cenderung menerima hak asasi manusia selagi memuat perjuangan kemanusiaan dan sesuai dengan semangat zaman.

Beberapa cendekiawan Muslim yang memilih kubu moderat, yaitu Abdullahi Ahmed An-Na'im, Mashood A. Baderin dan Muhammad 'Ābid al-Jābirī. Ketiganya membuat jembatan yang menegosiasikan hak asasi manusia dan hukum Islam agar saling melengkapi, berkesesuaian, dan kompatibel. Baderin, misalnya, memandang bahwa sejak abad ke-19 berbagai tantangan dan problem kekinian membuat metode-metode hukum Islam memerlukan peremajaan. Tantangan modernitas yang diakibatkan oleh hubungan Islam dan Barat yang semakin intim itu berdampak pada interaksi antar-manusia pada berbagai sektor, sehingga hukum Islam perlu mendedahkan dirinya dengan perspektif-perspektif yang kontemporer, tidak terkecuali menggunakan cara pandang hak asasi manusia. ${ }^{15}$

\footnotetext{
13 Pertentangan Hukum Islam dengan HAM dapat dilacak sejak PBB mengumumkan Universal Declaration of Human Right (UDHR) pada 1948. Secara reaktif, negara-negara mayoritas berpenduduk Muslim, khususnya Timur Tengah, menolaknya karena dianggap sebagai kolonialisme dalam bentuk baru pasca berakhirnya Perang Dunia II.

${ }^{14}$ Baca Hafiz, "Dinamika Hukum Islam", 202-203. Juga bisa dibaca dalam, Bassam Tibi, "Islamic Law/Shari'a, Human Rights, Universal Morality and International Relations”, 16 Human Rights Quarterly, Vol. 16, No. 2 (1994), 277-285. Sebagai informasi tambahan, untuk melihat perdebatan shari'ah dan HAM dalam perspektif sufi, bisa dibaca dalam, Fait A. Muedini. "Eximining Islam and Human Rights from the Perspective of Sufism", Muslim World Journal of Human Rights, Vol. 7, No. 1 (2010), 1-23.

15 Karya Mashood A. Baderin ini merupakan buku yang menjadi rujukan modern pertama dalam kajian Hukum Islam dan HAM Universal. Buku ini memberikan cara pandang yang jelas terhadap berbagai permasalahan inti, yang seringkali menjadi perdebatan antara Hukum Islam dan HAM. Selanjutnya baca lebih selengkapnya dalam karya Mashood A. Baderin, Hukum Internasional Hak Asasi Manusia dan Hukum Islam (Jakarta: Komnas HAM RI, 2010), 38-39.
} 
Kemudian, an-Na'im dalam pemikirannya menjelaskan bahwa HAM pada dasarnya merupakan gagasan universal, dan DUHAM merupakan instrumen penting untuk melindungi kemulian manusia dan untuk meningkatkan kesejahteraan setiap orang. An-Na'im memberikan satu contoh penerimaan hukum Islam terhadap hak asasi manusia yaitu pada kasus penghapusan perbudakan, yang tentu saja didasarkan pada asas persamaan dan kesetaraan antar sesama manusia sebagaimana juga termuat dalam HAM universal. ${ }^{16}$ Hal ini sebagaimana juga penerimaan hukum Islam yang mengacu pada ayatayat Makkīyah, yang lebih bersifat egaliter, tanpa membedakan jenis kelamin, keyakinan agama, ras dan lainnya. ${ }^{17}$ Pada pokok pemikirannya dalam mendudukkan HAM dan shari'ah, pemikir kelahiran Sudan ini memandang akan perlunya pembaruan hukum Islam dalam rangka menjawab tantangan modernitas.

Sedangkan menurut al-Jābirī, ada tiga kunci untuk memahami rasionalitas hukum-hukum shari' ${ }^{-6}$ ah Islam, yaitu universalisme shari' ${ }^{-} a h$ , hukum-hukum partikular, dan tujuan-tujuan, serta latar belakang. ${ }^{18}$ Untuk memahami berbagai masalah sosial yang meliputi sekat etnis, negara, agama dan geografi, maka al-Jābirī berargumen dibutuhkannya nilai universalitas, dan pendekatan HAM dapat dinegosiasikan dengan hukum-hukum yang bersumber dari ajaran Islam, karena hak asasi manusia yang didasarkan pada problem kemanusiaan dipandang sesuai dengan nilai-nilai hukum Islam.

Berbagai argumentasi yang dikemukakan oleh para cendekiawan Muslim tersebut diharapkan dapat mengakhiri perdebatan yang terusmenerus terjadi, yang pada akhirnya menjadi bangunan perspektif baru yang bisa dipraktikan oleh seluruh negara, khususnya bangsabangsa Muslim. Sebab, sharíah tanpa muatan HAM universal akan berdampak pada kekejian dan hilangnya nilai kemanusiaan individu. Sementara, HAM tanpa didasari konsep umum hukum Islam akan memberikan peluang yang seluas-luasnya bagi pelanggar hukum dan hilangnya keadaban moral yang tinggi.

\footnotetext{
16 Abdullah Ahmed An-Na'im, Islam and the Secular State: Negotiating the Future of Syariah (Massachusetts: Harvard University Press, 2008), 99.

17 Lihat selengkapnya dalam Abdullahi Ahmed an-Na'im. Dekonstruksi Syariah: Wacana Kebebasan Sipil, Hak. Asasi Manusia dan Hubungan Internasional dalam Islam, terj. Ahmad Suaedy dan Amirudin ar-Rany (Yogyakarta: LKiS, 2001), xix-xxiii.

${ }_{18}$ Baca dalam Muhammad Abid al-Jabiri, Syura Tradisi Partikularitas Universalitas, terj. Mujiburrahman (Yogyakarta: LKiS, 2003), 125-126.
} 
Apalagi, pada prinsipnya, sebagaimana yang juga diungkapkan oleh al-Jābirī, an-Na'im dan Baderin, sesungguhnya nilai-nilai hak asasi manusia sangat relevan dengan Hukum Islam. Kenyataan tersebut dapat dilihat dari lima pokok yang terangkum dalam aldrürìat al-khamsah atau hak-hak asasi manusia dalam Islam (al-huqūq alinsāniyah fi al-Isläm), yaitu: Penghormatan atas kebebasan beragama (bif. al-din); Penghormatan atas harta benda (bif Penghormatan atas jiwa, hak hidup dan kehormatan individu (bif zalnafs wa al-ird); Penghormatan atas kebebasan berpikir (bifzal-'aql); dan Keharusan untuk menjaga keturunan (bif za al-nasb). Lima pokok maqāsid al-shari' ${ }^{\prime}$ h tersebut dapat dijadikan sebagai tatanan konseptual, di mana antara HAM universal dan sharíah Islam memiliki perjumpaan yang sama dalam hal kemanusiaan. Keduanya sama-sama memberikan penghormatan terhadap kebebasan individu dengan individu yang lain, individu dengan masyarakat, masyarakat dengan masyarakat, serta masyarakat dengan negara.

Al-Qur'ān dan Hadīth sebagai sumber autentik hukum Islam juga memberikan penghormatan atas nilai-nilai kemanusiaan. ${ }^{19}$ Sebelum HAM universal menjadi kesepakatan bersama bagi sejumlah negara pemenang Perang Dunia II, al-Qur'ān sebagai sumber utama sharī'ah Islam telah memposisikan asas keadilan, penghapusan diskriminasi dan perjuangan terhadap masyarakat tidak mampu (mustad'afin) di atas visi pembelaan yang lain, nilai-nilai ini sama idealnya dengan yang diperjuangkan di dalam HAM universal.

Meski secara jelas antara HAM dan sharíah mempunyai persinggungan yang sama, masih saja ada sebagian pihak yang tetap memandang keduanya memiliki jarak. Jarak di antara keduanya ini senantiasa terpupuk sebagai sebuah perdebatan yang tidak ada habisnya, karena salah satu faktornya disebabkan minimnya usaha

19 Untuk memberikan penjelasan yang lebih lengkap bagaimana al-Qur'ān memberikan penghormatan yang tinggi terhadap hak asasi manusia dapatlah dicermati dari berbagai ayat yang membahas tentang keadilan, kebenaran dan kesetaraan. Di dalam al-Qur'ān terdapat sekira 80 ayat yang mengkaji mengenai pentingnya pemeliharaan hidup manusia dan penyediaan saran kehidupan. Salah satu ayat yang membahas hal ini, bisa ditelusuri pada surah al-Māidah: 32; Ada sekitar 50 ayat yang berbicara tentang ciptaan dan makhluk-makhluk, serta persamaan dalam penciptaan, misalnya pada surah al-Hujurāt: 13; Kemudian terdapat sekitar 320 ayat yang mengetengahkan sikap menentang kezaliman dan orang-orang yang berbuat zalim; lalu ada 50 ayat yang memerintahkan berbuat adil, dengan kata 'adl, qist, dan qișās. 
mendiseminasikan pemahaman mengenai kompatibilitas hak asasi manusia dan hukum Islam. Dialog yang berupaya untuk menegosiasikan "dua kutub" ini juga hampir tidak pernah terjadi. Tak pelak, bila isu-isu kontemporer yang mengemuka yang bersinggungan dengan hak asasi manusia seringkali menjadi wacana yang memanas, bahkan berujung pada ujaran kebencian oleh sebagian pihak.

Hingga saat ini yang secara konsisten banyak bekerja memberikan pemahaman hak asasi manusia hanya lembaga swadaya masyarakat. Sementara perguruan tinggi yang mestinya diharapkan bisa mengakomodasi ruang yang lebih besar, belum bekerja secara optimal. Tentu saja persoalan ini patut disesalkan secara bersama mengingat mayoritas penduduk negeri ini beragama Islam, dan Indonesia juga menjadi salah satu negara yang telah meratifikasi dan mengadopsi DUHAM ke dalam UUD $1945 .^{20}$

Akibat minimnya pemahaman tersebut, implementasi terhadap UUD 1945 Pasal 28 seringkali tidak sesuai dengan yang diharapkan. Faktanya, jaminan dan penghormatan terhadap kebebasan beragama seperti yang diundangkan dalam pasal 28 tersebut, masih di persimpangan jalan. ${ }^{21}$ Beberapa kali aksi persekusi terhadap umat beragama berbeda keyakinan atau penghancuran rumah ibadah terjadi di sejumlah daerah di Indonesia, dan tampaknya problem sosialkeagamaan ini akan terus menjadi bola panas yang sewaktu-waktu akan membakar rajutan kehidupan beragama selama diseminasi pemahaman HAM dan hukum Islam tidak diberikan ruang dialog yang lebih intensif, baik yang melibatkan LSM, perguruan tinggi, maupun organisasi sosial keagamaan.

${ }^{20}$ Lahirnya DUHAM pada 10 Desember 1948 di Paris merupakan respons dari mayoritas warga dunia bahwa semua manusia dilahirkan dengan kebebasan dan memiliki kesamaan derajat di depan hukum. Sebelum DUHAM lahir, para pendiri negeri ini sudah jauh lebih dulu memikirkan pentingya perlindungan terhadap HAM. Hal ini dapat dilihat dalam pasal 28 UUD 1945. Kendati awalnya, soal HAM itu hanya dicantumkan secara umum, pasca era reformasi 1998, pasal 28 itu kemudian diamandemen beberapa kali sehingga jangkauan HAM pada UUD 1945 saat ini akhirnya benar-benar merefleksikan DUHAM 1948.

21 Untuk melihat penjelasan yang lebih lengkap mengenai diskursus HAM dan Kebebasan Beragama di Indonesia, baca dalam Syamsul Arifin, "Indonesian Discourse on Human Rights and Religious Freedom", dalam Brigham Young University Law Review (2012), 775-810. 


\section{Perjumpaan dan Persinggungan}

Pada awal naskah ini telah dijelaskan bahwa umat Islam di Indonesia belum bisa menerima prinsip-prinsip HAM secara penuh. Setiap kali terjadi pelanggaran HAM yang bersentuhan dengan umat Islam selalu diwarnai dengan penolakan, baik dengan ujaran kebencian maupun tindak kekerasan. Demi kepentingan hal tersebut, pada sub bab ini akan dijelaskan mengenai beberapa diskursus HAM dan Hukum Islam yang kerap melahirkan pertentangan, apa saja diskursus tersebut dan bagaimana menemukan titik perjumpaan di antara keduanya. Beberapa diskursus tersebut di antaranya, yaitu: (1) Kebebasan Beragama dan Berkeyakinan; (2) Pernikahan Beda Agama; dan (3) Lesbian, Guy, Biseksual dan Transgender

Pertama, Kebebasan Beragama dan Berkeyakinan (KBB). Shahram Akbarzadeh dan Benjamin MacQueen dalam kertas kerjanya bertajuk "Framing the Debate on Islam and Human Rights", memberikan catatan bahwa perdebatan antara HAM dan Hukum Islam hingga saat ini masih sering memperkarakan tentang KBB. ${ }^{22}$ Bagi banyak umat Islam di Indonesia, pasal kebebasan beragama yang termuat dalam HAM universal tidak relevan dengan ajaran sharíah. Penolakan terhadap pasal-pasal yang memberikan jaminan perlindungan terhdap $\mathrm{KBB}$ sangat parah. Bahkan, berbagai aksi pelanggaran KBB terus terjadi setiap tahun. Sepanjang 2016, sebagaimana riset yang dilakukan Setara Institute, terdapat 208 jenis pelanggaran KBB. Pelanggaran tersebut berupa 270 tindakan yang terjadi di 24 provinsi. Kemudian pada awal 2017, publik disentakkan kembali dengan laporan Komnas HAM yang menyebut terjadinya enam kasus pelanggaran $\mathrm{KBB} .{ }^{23}$

22 Pembahasan banyak menyinggung soal status perempuan, karena ayat-ayat alQur'ān banyak menyoroti sejumlah masalah perempuan, khususnya mengenai keberadaan mereka di hadapan hukum, keluarga dan pembagian hak waris. Lihat selengkapnya dalam Shahram Akbarzadeh dan Benjamin MacQueen, "Framing the Debate on Islam and Human Rights", dalam Shahram Akbarzadeh dan Benjamin MacQueen (eds.). Islam and Human Rights in Practice: Perspective across the Ummah (London: Routladge, 2008), 1-11.

${ }^{23}$ Enam kasus tersebut adalah: (1) Jemaah Ahmadiyah Indonesia (JAI) Kota Banjar yang mengajukan permohonan pencabutan SK Walikota Banjar Nomor 450/Kpts/.115.Huk/2011 tentang Pembekuan Aktivitas Jemaat Ahmadiyah; (2) pengaduan dari pengurus Gereja Isa Almasih TPI Ngentak, Sleman, Yogyakarta mengenai sulitnya mengurus IMB rumah ibadah; (3) Persekutuan Doa Nazarenus Tanah Runtuh di Kecamatan Takari, Kabu. Kupang, yang dituduh sebagai aliran sesat; (4) Penyegelan masjid milik JAI Kota Depok; (5) Intimidasi terhadap jemaat 
Berbagai gangguan pelanggaran $\mathrm{KBB}$ meliputi pelarangan dan perusakan rumah ibadah, ancaman dan penyesatan kelompok minoritas agama, serta pemaksaan keyakinan.

Dalam tiga tahun terakhir, sebagaimana laporan Setara Institute (2015-2017) tentang prospek HAM di Indonesia, pelanggaran KBB adalah yang paling berat. Pelanggaran hak KBB senantiasa lestari, karena dilatarbelakangi oleh peran dari dua aktor. Aktor pertama dilakukan oleh negara itu sendiri, sementara yang aktor keduanya merupakan masyarakat. Tampak dari setiap kejadian bersentimen $\mathrm{KBB}$, negara sering tidak hadir untuk menindak tegas kepada para pelaku perusakan rumah ibadah dan penyerangan kelompok minoritas keagamaan/kepercayaan, birokrasi yang mempersulit pendirian gereja atau masjid, serta pihak-pihak yang memaksakan keyakinan seseorang. Pengabaian seperti ini yang secara tidak langsung "memotivasi" kelompok tertentu untuk bersikap sewenang-wenang terhadap kelompok agama yang tidak sepaham dengannya.

Bagaimanapun alasannya, tindakan pembiaran yang dilakukan negara tidak dapat dibenarkan. Hal tersebut sama seperti negara tidak memberikan jaminan perlindungan terhadap KBB. Sekalipun dilakukan penindakan tegas, hukuman terhadap pelaku penyerangan tidak setimpal dengan apa yang sudah diperbuat. Persoalan ini nyata terjadi di negeri ini, dan tidak dapat dipastikan kapan pemerintah dapat menyudahi-atau paling tidak mengurangi-berbagai pembiaran pelanggaran terhadap KBB. Pada tahun ini, dari aktor negara (mayoritas dilakukan pihak kepolisian), tindakan yang paling banyak melanggar kebebasan beragama yaitu diskriminasi sebanyak 21 kasus, pembiaran 17 kasus, dan tindakan kebijakan diskriminatif dengan 13 kasus. ${ }^{24}$ Pelanggaran yang disebut terakhir ini sangat ironis karena negara secara nyata mempertontonkan arogansinya dengan bertindak membuat kebijakan yang membelenggu kelompok minoritas keagamaan. Hal ini dapat dilihat, misal pada terbitnya Surat Keputusan Nomor 450/Kpts.115.Huk/2011 mengenai pembekuan aktivitas Jemaat Ahmadiyah Indonesia (JAI) Kota Banjar oleh Walikota Banjar; lalu ditandatanganinya Peraturan Gubernur Jawa Barat Tahun 2011 mengenai pelarangan kegiatan JAI di Jawa Barat

Gereja Kristen Protestan Maluku Tenggara Raya di Desa Taar; dan (6) Ancaman pemberhentian sebagai karyawan STAIN Kediri karena tidak salat berjemaah.

24 Dikutip dari http://nasional.kompas.com/read/2017/01/29/17012251/ada. 208.pelanggaran.kebebasan.beragama.sepanjang.2016 
menyusul diterbitkannya Surat Keputusan Bersama Menteri Agama, Jaksa Agung dan Menteri Dalam Negeri Nomor 3 Tahun 2008, Nomor Kep-033/A/JA/6/2008 dan Nomor 199 Tahun 2008 tentang Peringatan dan Perintah kepada Penganut, Anggota, Pengurus JAI dan warga masyarakat.

Pelanggaran hak KBB oleh negara sebenarnya telah dimulai sejak lama. Diterbitkannya UU. No.1/PNPS.1965 pada pemerintahan Soeharto menjadi ihwal dimulainya perlakuan diskriminasi terhadap kelompok penganut agama/kepercayaan lokal. Poin penting yang hingga saat ini dipersoalkan para pemeluk agama/kepercayaan lokal dan kalangan pembela HAM karena di dalam UU yang dimaksud hanya menyebutkan enam agama yang dipeluk masyarakat Indonesia (Islam, Katolik, Protestan, Budha, Hindu dan Kong Hu Chu), sehingga regulasi yang awalnya bertujuan untuk mencegah terjadinya penyalahgunaan dan penodaan agama, justru menjadi alat legitimasi untuk melakukan tindakan diskriminasi dan kekerasan terhadap agama dan kepercayaan lokal, bahkan aliran-aliran agama. Selain itu, UU tersebut juga melahirkan istilah-istilah yang peyoratif, bahwa enam agama yang tercantum dalam UU No.1/PNPS.1965 sebagai agama yang sah diakui pemerintah, sementara ratusan agama lokal, adalah agama tidak resmi. ${ }^{25}$

Pelanggaran terhadap KBB oleh negara, secara tidak langsung, memberikan kesempatan bagi masyarakat untuk melakukan hal yang sama. Dengan kata lain, masyarakat juga menjadi aktor yang melakukan pelanggaran KBB setelah adanya peluang dari negara. Tetapi pelanggaran yang dilakukan oleh masyarakat tidak melulu disebabkan oleh peluang yang diberikan negara. Cara pandang yang sesat pikir dalam memahami doktrin keagamaan yang menyebabkan tertutupnya masyarakat dalam memahami doktrin agama. Keberagamaan yang ekslusif (religious exclusivism) tersebut menjadikan orang fanatik terhadap agama dan kelompoknya, sehingga menganggap apa yang diyakininya sebagai yang paling benar dan

\footnotetext{
${ }^{25}$ Untuk hal ini baca selengkapnya dalam M. Syafi'ie, "Ambiguitas Hak Kebebasan Beragama di Indonesia dan Posisinya Pasca Putusan Mahkamah Konstitusi”, Jurnal Konstitusi, Vol. 5, No. 8 (Oktober, 2011), 675-705. Sementara itu, untuk pengetahuan lebih menyeluruh tentang kajian pembatasan hak kebebasan beragama di Indonesia, baca Muwaffiq Jufri, "Pembatasan terhadap Hak dan Kebebasan Beragama di Indonesia", Jurnal Ilmiah Pendidikan Pancasila dan Kewarganegaraan, Vol. 1, No. 1 (Juni, 2016), 40-47.
} 
menilai agama dan keyakinan lain salah. ${ }^{26}$ Menurut Runzo, mestinya agama bisa dijadikan sebagai sumber energi bagi penegakan HAM karena substansinya yang memperjuangkan nilai-nilai kemanusiaan universal, sekalipun dalam kesepakatan pembentukan HAM tidak melibatkan agama.

Dasar hukum yang menjamin KBB sudah diatur dalam konstitusi Indonesia melalui Pasal 28E ayat (1) UUD 1945. Terlebih lagi, hak KBB merupakan HAM yang berlaku secara universal serta dikodifikasi dalam instrumen internasional HAM. Kemudian, pada tingkat normatif KBB merupakan hak dasar, yang telah dirumuskan dalam pasal 18 DUHAM serta Kovenan Internasional tentang Hakhak Politik dan Sipil (the International Covenant on Civil and Political Rights), di mana Indonesia menjadi salah satu negara yang telah meratifikasinya. Sementara, jika mempelajari studi Islam, maka sejarah Islam semenjak abad ke-7 M telah berbicara tentang kebebasan, termasuk kebebasan beragama atau berkepercayaan. ${ }^{27}$ Al-Qur'ān juga memberikan pengakuan terhadap kebebasan beragama seperti yang terdapat dalam al-Baqarah (ayat 256), al-Shūrā' (ayat 48), al-Ghāshiyah (ayat 21), Yunus (ayat 99), al-Kahf (ayat 29), Qāf (ayat 45), dan alKāfirūn (ayat 6). Ayat-ayat tersebut, menurut Mohammad Hashim Kamali, merupakan bukti bahwa Islam merupakan agama yang memberi penguatan (affirmative) terhadap kebebasan beragama dan pluralisme. ${ }^{28}$

Dalam beberapa ayat al-Qur'ān di atas secara jelas, doktrin Islam memberikan kewenangan terhadap seluruh manusia untuk menentukan jalan hidupnya dalam beragama. Prinsip kesukarelaan dalam beragama ini tersirat dengan sangat tegas dalam ayat-ayat tersebut. Bahkan, dalam surah Yūnus ayat 99 menyatakan bahwa umat Islam diperintahkan untuk memberikan penghormatan dan penghargaan terhadap pemeluk agama yang berbeda. Tapi sebaliknya, kita tidak memungkiri bahwa ada ayat-ayat lain yang setelah ditafsirkan oleh kelompok tertentu, menjadi legitimasi bagi segala

\footnotetext{
${ }^{26}$ Joseph Runzo, Nancy M. Martin, and Arvind Sharma, "Introduction,", dalam Joseph Runzo, Nancy M. (eds.), Human Rights and Responsibilities in the Modern Religions (Oxford: Oneworld Publications, 2003).

27 Wahyu Hidayati, Apakah Kebebasan Beragama: Bebas Pindah Agama? Perspektif Huk.um Islam dan HAM (Salatiga: STAIN Salatiga Press, 2008).

28 Mohammad Hashim Kamali, An Introduction to Shariah (Selangor: Ilmiah Publisher, 2006).
} 
tindakan mereka untuk membenci, mengancam bahkan melakukan pengusiran terhadap kelompok berkeyakinan berbeda.

Pertimbangan teologis seperti ini, baik eksklusif maupun inklusif, tidak bisa diabaikan pengaruhnya dalam diskursus dan praksis kebebasan beragama atau berkeyakinan. Mengikuti penjelasan teoritik dalam sosiologi bahwa tindakan manusia antara lain dipengaruhi oleh sistem makna yang dimilikinya, maka persoalan KBB di Indonesia juga bisa dirunut pada sistem makna yang digunakan oleh masyarakat. Hanya saja sistem makna tersebut harus diorientasikan penafsirannya secara progresif sehingga teks yang mulanya mati menjadi sangat sensitif menyentuh problem kemanusiaan. Pada akhirnya, HAM dan sharī'ah menjadi basis hukum yang tidak saling bersinggungan, melainkan saling berjumpa dalam menyelesaikan problem kemanusiaan universal.

Kedua, Pernikahan Beda Agama. Indonesia dikenal sebagai bangsa yang besar. Jumlah penduduknya mencapai 237 juta jiwa (BPS, 2010), yang terdiri dari 17 ribu pulau, 1.340 suku bangsa, serta 300 kelompok etnik. Dari besarnya jumlah penduduk itu, mayoritas beragama Islam (87\%), Katolik (2,9\%), Kristen Protestan (6,9\%), Buddha (0,05\%), Hindu $(1,69 \%)$ dan Kong $\mathrm{Hu} \mathrm{Chu}(0,13 \%)$. Gambaran ini menjelaskan kepada publik bahwa penduduk negeri ini sangat multikultural. Atas latarbelakang keberagaman itu para pendiri bangsa (founding fathers) kita dahulu bersepakat menjadikan Pancasila-yang bersemboyankan Bhinneka Tunggal Ika—sebagai ideologi negara.

Pada konteks hari ini, di mana kebutuhan tenaga kerja di berbagai sektor industri memprioritaskan keahlian dan pengalaman, maka perjumpaan orang dalam satu kantor dari berbagai latarbelakang daerah, suku dan agama menjadi tidak terhindarkan. Intensitas pertemuan yang begitu ketat di antara pegawai, seperti yang hari ini banyak terjadi, mendorong pegawai laki-laki menaruh hati kepada pegawai perempuan. Pada awalnya merupakan partner kerja, lambat laun saling jatuh cinta dan akhirnya mengikat janji suci meski kadang berbeda keyakinan agama. Fakta ini adalah satu contoh yang sekarang banyak terjadi di berbagai kantor di sejumlah kota besar, seperti Jakarta, Bandung dan Surabaya. Masalahnya, sebagian besar Muslim di negeri ini masih banyak yang menolak pernikahan beda agama (interfaith marriage). Penolakan tersebut dilandasi dalil agama yang bersumber dari dua ayat al-Qur'ān surah al-Baqarah ayat 221 dan alMumtahanah ayat 10. 
Pada kedua ayat tersebut, ada dua pernyataan penting yang membutuhkan lebih dari sekadar pemahaman tekstual agar dalam membaca pesan keduanya tidak menimbulkan kesalahan, sehingga berdampak pada produk hukum yang akan dihasilkan. Pernyataan pertama, dari ayat yang pertama, mengenai larangan laki-laki Muslim untuk menikahi perempuan musyrik, dan sebaliknya wanita beriman menikahi laki-laki musyrik. Kemudian, pernyataan kedua, dari ayat kedua, mengenai larangan wanita beriman menikahi laki-laki kafir, dan sebaliknya laki-laki beriman menikahi perempuan kafir. Jika diartikan secara literal dan kaku, kesimpulan yang akan didapatkan sangat mudah bahwa laki-laki Muslim dilarang menikah dengan perempuan musyrik atau kafir, serta sebaliknya. Apalagi, pandangan yang umum pada umat Islam di Indonesia, mengatakan bahwa yang dimaksud musyrik dan kafir adalah non-Muslim. Itu berarti, laki-laki Muslim dilarang menikahi perempuan yang berasal dari agama Kristen, Budha, Hindu, Protestan atau keyakinan lokal lainnya, serta sebaliknya.

Kedua ayat yang disebut di atas kiranya perlu untuk diterjemahkan secara progresif melalui pendekatan historis dan humanis. Kata "musyrik" atau "kafir" seringkali dilekatkan pada umat non-Muslim. Pernyataan tersebut tidak dapat dikatakan benar, sekalipun Kristen dan Yahudi melakukan perbuatan syirik karena umat Yahudi menganggap Uzair sebagai anak Tuhan (al-Māidah: 30) dan umat Kristen menempatkan Allah itu ialah al-Masīh putra Maryam (alMāidah:17) dan Allah sebagai yang ketiga dari Trinitas (al-Māidah: 73), juga al-Masih sebagai anak Tuhan (al-Tawbah: 30). Sebab, Allah sendiri tidak pernah di dalam al-Qur'ān menyebut Kristen dan Yahudi sebagai musyrik atau kafir tetapi Ahli Kitab (al-Nisā’’171), (alMāidah:5), ('Al 'Imrān: 64). Dapat dipahami dari sini, sesungguhnya tidak bisa secara langsung orang yang berbuat syirik disebut sebagai musyrik atau kafir, karena untuk kedua kata ini masing-masing ada tingkatannya (seperti kafir ingkar, kafir juhud, kafir munafik, kafir syirik, kafir nikmat, kafir murtad dan kafir Ahli kitab). ${ }^{29}$

Secara historis, seperti yang pernah dipertanyakan oleh Muḥammad 'Abduh dan M. Rashīd Riḍā dalam Tafsir al-Mannār mempertanyakan apakah perempuan-perempuan musyrik yang

29 Baca selengkapnya dalam Mun'im Sirry (ed.), Fiqib Lintas Agama: Membangun Masyarakat Inklusif-Pluralis (Jakarta: Yayasan Waqaf Universitas Paramadina, 2003), 153-165. 
dimaksud dalam surah al-Baqarah: 221 itu masih ada di daerah Arab sekarang ini. Kalau ada hukum itu berlaku, dan jika tidak ada maka hukum ini tidak berlau sehingga tidak menghalangi perkawinan beda agama. ${ }^{30} \mathrm{Hal}$ ini karena yang dimaksud "musyrik" dan "kafir" dalam surah tersebut adalah orang-orang yang tidak memiliki kitab suci, tidak mempercayai nabi-nabi Allah, dan penyembah berhala, sementara Yahudi dan Kristen bukan dari kelompok ini. ${ }^{31}$ Selain itu, dilihat dari konteks sejarahnya, memang ayat ini turun saat tengah terjadi ketegangan antara umat Islam dengan kelompok musyrik, sehingga ayat-ayat yang menjadi dasar pelarangan nikah beda agama bagi sebagian kelompok Muslim, murni ayat-ayat ijtihadi sehingga memungkinkan adanya penafsiran yang lain selagi bisa dipertanggungjawabkan kaidah penarikan dan kesimpulan dari produk hukum yang akan dihasilkan nantinya.

Kemudian, secara humanis, ayat-ayat tersebut perlu dilakukan pendekatan dengan mengarusutamakan hak-hak dasar kemanusiaan. Dalam perspektif HAM, menikah merupakan hak fundamental setiap orang yang sangat inheren dengan kebebasan individu, sehingga jaminan terhadapnya dilindungi oleh hukum HAM internasional, tak terkecuali bila ada perempuan Muslim menikah dengan laki-laki Kristen atau sebaliknya. Secara ideal, manusia sebagai makhluk individu memiliki hak dasar yang kodrati untuk menentukan pilihan hidupnya tanpa harus ada campur tangan dari pihak lain, bahkan agama sekalipun. Karena hak dasar itulah, seorang perempuan boleh memilih menikah dengan lelaki pilihannya. Dalam hukum HAM universal, hak dasar perempuan itu dijamin dalam beberapa instrumen HAM, di antaranya Universal Declaration of Human Rights (UDHR), the Convention on Elimination of all Discrimination Againts Women (CEDAW), dan the International Covenant on Social, Political, and Cultural Rights (ICSPCR). Ketiga instrumen internasional ini memuat sejumlah pasal yang menjamin setiap perempuan untuk terbebas dari perilaku diskrimnasi, subordinasi, eklusi sosial, berbagai bentuk ganggungan dan pembatasan hanya karena jenis kelamin mereka. Di dalam UDHR, misalnya, secara eksplisit disebutkan mengenai jaminan

${ }^{30}$ Muhammad 'Abduh dan Muhammad Rashīd Riḍā, Tafsir al-Mannār, Vol. 6 (Beirut: Dār al-Ma'rifah, t.th.), 29-31. Dikutip dari Mun'im Sirry (ed.), Fiqih Lintas Agama, 160.

${ }^{31}$ Lihat dalam Abū Ja'far Muḥammad b. Jarīr al-Ṭabarī, Jāmi' al-Bayān 'an Ta'mūl Ay al-Qur'ān, dikomentari Șidqī Jāmil al-Aț̣āar, Vol. 2 (Beirut: Dār al-Fikr, 2001), 467. Dikutip dari Mun'im Sirry (ed.), Fiqih Lintas Agama, 16. 
penghormatan terhadap laki-laki dan perempuan yang cukup umur (baca: dewasa) — t idak ada batasan ras, suku, bangsa atau agamauntuk dapat menjalani pernikahan dan membangun keluarga secara sah. $^{32}$

Ketiga, LGBT (Lesbian, Gay, Biseksual dan Transgender). Satu persoalan lagi, yang tak kalah rumit dibanding sejumlah masalah HAM lainnya yang bersentuhan dengan kelompok Muslim, yaitu mengenai LGBT. Di berbagai negara, tak terkecuali di Indonesia, komunitas LGBT mulai berani membuka identitasnya secara terbuka dalam beberapa tahun terakhir. Hal ini sebagai salah satu dampak atas semakin tolerannya bangsa-bangsa di Benua Biru yang mulai mengeluarkan kebijakan tentang penghormatan, perlindungan dan penegakan hukum terhadap pelaku LGBT, yang kemudian berimbas ke banyak negara di dunia. Inggris, misalnya, yang sebelumnya memberi hukuman bagi pelaku LGBT, sekarang pemberlakuan hukum yang tidak manusiawi itu dihapus.

Di Indonesia sendiri, sebelumnya orang-orang yang memiliki orientasi seksual berbeda dibanding pada umumnya ini kerap takut dan malu kalau identitasnya diketahui publik. Tapi berkat era keterbukaan informasi yang tumbuh begitu cepat, disusul dengan fasilitas media sosial yang berjubel, komunitas LGBT mulai berani berinteraksi secara terbuka. Pada beberapa kesempatan, para pelaku LGBT berani mengakui identitasnya di depan publik, baik melalui aksi demonstrasi maupun undangan sebagai pembicara dalam sebuah seminar atau workshop.

Argumentasi penerimaan dan penolakan terhadap LGBT senantiasa saling tarik-menarik. Pihak yang menolak berpandangan bahwa LGBT bertentangan dengan hukum Islam, tidak sesuai dengan fitrah manusia, tidak memelihara akhlak, serta tidak tertib sosial karena merusak tatanan hidup berkeluarga dan bermasyarakat. M. Quraish Shihab berpendapat, pernikahan atau hubungan seks sesama jenis tidak dibenarkan dalam ajaran Islam. Terkait dengan alasan hak asasi manusia seperti banyak disuarakan oleh aktivis HAM, kata

\footnotetext{
32 Mengenai jaminan perlindungan terhadap pernikahan beda agama, lihat dalam Ibrahim Imam, "Shariah and Human Rights Perspective on Interfaith Marriage: Challenges Impeding its Practice in Nigeria" Islam and Civilisational Renewal Journal, Vol. 7, No. 4 (2016), 492-508. Sebagai referensi tentang topik ini, baca juga dalam Md. Kamruzzaman, "Interreligious Marriage in Bangladesh: From Human Rights", International Journal of Education, Culture and Society, Vol. 1, No. 2 (September, 2016), 44-51.
} 
Quraish, adalah dalih yang tidak begitu saja dapat dibenarkan. Fenomena LGBT telah menjungkirbalikkan hakikat kemanusiaan. Meski begitu, umat Islam tidak boleh berbuat semena-mena terhadap kaum LGBT. Mereka membutuhkan pertolongan supaya bisa menghilangkan penyakit homoseks/lesbian. ${ }^{33}$

Argumen penolakan juga datang dari Majelis Ulama Indonesia (MUI). Melalui Fatwa Nomor 57 Tahun 2014 tentang Lesbian, Gay, Sodomi dan Pencabulan, MUI mengharamkan aktivitas kaum LGBT karena merupakan bentuk kejahatan. Fatwa ini juga menyebutkan bahwa aktivitas seksual menyimpang kaum LGBT dapat disimpulkan sebagai delik umum dan kejahatan yang menodai martabat luhur manusia. Pelaku homoseksual, baik lesbian maupun gay, termasuk biseksual dikenakan hukuman hadd dan/atau ta'zir oleh pihak berwenang. Ketua Umum MUI Ma'ruf Amin mengatakan, sebagaimana dikutip dari Kompas (17 Februari 2016), LGBT tidak sesuai dengan konstitusi, bertentangan dengan sila pertama dan kedua Pancasila, serta hukum agama. Selain itu, LGBT bertentangan dengan Undang-undang Dasar 1945, khususnya Pasal 29 ayat 1 dan Pasal 28 $\mathrm{J}$.

Sementara Masfuk Zuhdi mengatakan, pelaku LGBT telah melakukan dosa besar karena berani melawan sunnatullah, serta menentang norma agama dan sosial, meski dengan berbagai pembelaan ilmiah dan teologi yang apriori. Pembelaan-pembelaan yang dilakukan secara sistematis yang membuat gerakan LGBT tumbuh menyebar sebagai epidemi sosial. ${ }^{34}$ Hukum Islam sendiri, kata Ramlan Yusuf Rangkuti, menjadi keniscayaan dengan menolak penyimpangan seksual seperti homoseksual tersebut. ${ }^{35}$

Argumen penolakan yang dikemukakan oleh sejumlah akademisi dan ulama Muslim di Indonesia tersebut bukanlah berdiri sendiri. Penolakan mereka terhadap LGBT didasarkan pada pemikiran sejumlah ulama kenamaan, misalnya Rasyid Ridha, Murtadha Mutahhari, Abdul Malik Karim Amrullah (Buya Hamka) dan 'Abd alRaḥmān al-Jazāirī. Seperti dikutip Ramlan Yusuf dalam artikelnya bertajuk Homoseksual dalam Perspektif Hukum Islam, Abdurrahman Al-

\footnotetext{
33 https://www.republika.co.id/berita/nasional/umum/16/03/03/o3gqlz361-inikata-quraish-shihab-soal-kaum-lgbt. (dikutip dari Republika.co (Selasa, 16/10/2017).

${ }^{34}$ Masjfuk Zuhdi, Masail Fiqhiyah (Jakarta: Karya Unipress, 1988), 1.

35 Ramlan Yusuf Rangkuti, "Homoseksual dalam Perspektif Hukum Islam”, Jurnal Asy-Syir'ah, Vol. 46, No. 1 (Januari-Juni 2012), 210-211
} 
Juzairi berpendapat, homoseksual merupakan perbuatan keji sebagaimana jarimah zina. Keduanya termasuk dosa besar, dan merupakan perbuatan yang tidak sesuai dengan fitrah manusia. ${ }^{36}$ Murtadha Mutahhari menengarai, menyebarnya tren gaya hidup seks sesama jenis diakibatkan ketersediaan sarana pembangkit api syahwat menyimpang bernaluri hewaniah. Karena ketersediaan sarana tersebut, tren menjadi gay dan lesbian (pelaku homoseks) tidak hanya dilakukan oleh orang-orang ateis, tetapi juga orang beragama yang mengagungkan materialisme, dan meninggalkan nilai spiritual yang mereka anut. ${ }^{37}$

Lebih dari itu, seperti disimpulkan Ramlan Yusuf, penolakan terhadap LGBT juga didasarkan pada pendapat empat ulama fiqh, yaitu Mālikìyah, Shāfíìyah, Ḥanābilah dan ḤAnafìyah. Keempat ulama ini sepakat memberikan tiga jenis hukuman bagi pelaku seks sesama jenis, yaitu: (1) dibunuh secara mutlak, baik pelakunya perjaka (bikr) maupun muḅsān (beristri); (2) dijatuhi hukuman seperti pelaku zina. Jika perjaka dihukum dera atau diasingkan, dan jika sudah berkeluarga dihukum rajam; (3) dikenakan hukuman ta'zir, sejenis hukuman yang bertujuan edukatif dan preventif. ${ }^{38}$

Penolakan para cendekiawan dan ulama Muslim terhadap LGBT juga dirujukkan pada beberapa ayat al-Qur'ān, khususnya yang bekisah tentang pengingkaran umat Nabi Luth, seperti pada surah al-Shū'arā': 165-166, an-Naml: 54-55, dan al-A'rāf: 80-81. Ketiga ayat tersebut dijadikan alasan yang kuat bagi MUI tentang pelarangan aktivitas kaum LGBT. Ketiga firman Allah ini, bagi MUI, secara jelas melarang hubungan seksual sesama jenis dan mensifatinya sebagai perbuatan keji, berlebih-lebihan dan melampaui batas.

Namun cendekiawan Muslim Munim Sirry memiliki argumen yang berbeda tentang umat Nabi Luth AS yang diceritakan dalam beberapa ayat al-Qur'ān (al-A'rāf: 80-81, al-Shu'arā': 165-166; dan alNaml: 55), yang kerap dijadikan dasar penolakan sebagian umat Islam terhadap LGBT. Menurutnya, ayat-ayat tersebut tidak cukup untuk dijadikan rujukan atas penolakan kaum LGBT karena tidak dijelaskan secara eksplisit mengenai pelarangan orientasi seksual sesama jenis. Peringatan Nabi Luth kepada kaumnya dalam al-Shu'arā': 165-166

\footnotetext{
36 'Abd al-Raḥmān al-Jazāirī, Kitāb al-Fiqh al al-Madhāhib al-Arba'ah, Vol. 5 (Beirut:

Dār al-Fikr al-'Arabī, t.th), 113.

${ }^{37}$ Murtadha Mutahhari, Manusia dan Agama (Bandung, Mizan: 1984), 58.

${ }^{38}$ Rangkuti, "Homoseksual”, 210-211.
} 
oleh Mun'im Sirry, bukan dimaksudkan untuk melarang hubungan sesama jenis melainkan larangan berselingkuh, berzina, serta hukuman bagi kaumnya yang mengingkari misi kenabiannya. Hal ini dia kuatkan dengan merujuk pada pandangan ulama Ibn Hazm al-Andalūsī (w. 1064) dalam Kitab al-Muhallä, yang menolak mengaitkan azab kaum Luth dengan perbuatan seks sesama jenis, tapi justru karena penolakan mereka terhadap ajakan Nabi Luth dan misi kenabiannya. ${ }^{39}$

Tentu, cara pandang berbeda dalam memahami ayat-ayat yang berkisah tentang kaum Nabi Luth oleh Mun'im Sirry tersebut dapat memicu perdebatan. Namun, sebagai sebuah upaya sungguh-sungguh untuk melakukan penafsiran, perspektif tersebut patut menjadi argumentasi yang dapat dipertimbangkan secara mendalam. Apalagi, dalam sebuah pemahaman atas sumber keagamaan, tidak pernah ada tafsir tunggal yang paling benar, sehingga sebagai sebuah produk penafsiran sangat perlu diapresiasi.

Satu aspek yang membedakan cara pandang tersebut dengan yang selama ini telah menjadi pemahaman mainstream, yaitu dikedepankannya perasaan kemanusiaan atas keberadaan kaum LGBT. Selain itu, pada akhirnya, argumentasi yang demikian tersebut dapat dijadikan dasar legitimasi bagi pernikahan sejenis. Pada tingkat ini, tampak pendapat Mun'im ini lebih melihat kepada kemaslahatan, sebagaimana yang juga dia ungkapkan, bahwa setiap individu memiliki hak dasar kemanusiaan yang tidak bisa dikekang oleh siapapun selagi tidak membuat hak orang lain terciderai. Konsep kemaslahatan seperti ini sangat penting untuk dijunjung agar dapat terwujud kondisi sosial yang adil, setara dan berorientasi pada nilai-nilai kemanusiaan. Dengan begitu, spirit Islam yang mengedepankan aspek penghormatan kepada nilai kemanusiaan universal akan berjalan seiring dengan perkembangan zaman.

\section{Penutup}

HAM dan sharīah senantiasa memiliki titik perjumpaan karena pada prinsipnya, keduanya sama-sama memperjuangkan nilai kemanusiaan. Persinggungan di antara keduanya sering terjadi-dan itu menjadi umum adanya, karena basis pengembangan hukum keduanya bermula dari sumber yang berbeda. HAM berasal dari

\footnotetext{
${ }^{39}$ Baca selengkapnya dalam, https://www.inspirasi.co/dennyja/5806_mun-im-sirrymenafsir-kisah-nabi-luth-secara-berbeda. Dikutip pada Jum'at (19 Oktober 2017), pukul 17.16
} 
rasionalitas manusia, sementara sharíah berangkat dari wahyu Allah. Sangat wajar bila berbagai perdebatan muncul sebagaimana pada umumnya sebuah diskursus pengetahuan. Hanya saja yang perlu dipahami bahwa pertentangan dan ketegangan yang muncul, tidak boleh berujung pada kekerasan.

Pada satu sisi, kelompok Muslim yang menolak prinsip-prinsip HAM tidak diragukan keberadaannya. Tetapi, pada sisi yang lain, banyak Muslim juga dengan lapang dada menerima HAM. Mereka yang bersikap inklusif ini berpandangan bahwa di antara keduanya memiliki visi yang sama dalam menyuarakan keadilan, perdamaian, kesetaraan, dan toleransi. HAM tidak perlu dipandang sebagai konsep yang bertentangan dengan Islam, di samping karena telah banyak negara berpenduduk mayoritas Islam mengakui dan meratifikasi instrumen HAM yang dikeluarkan PBB.

Secara teologis, Islam memiliki sumber autentik yang dapat dijadikan legitimasi penerimaan umat Islam terhadap HAM. Terdapat banyak ayat yang dapat meneguhkan ide-ide utama HAM yang muncul dari Barat, seperti yang termuat pada beberapa surah dalam al-Qur'ān yang mengindikasikan pengakuan Islam terhadap kebebasan beragama dan berkeyakinan, sebagaimana yang ditekankan dalam HAM internasional.

Meski landasan penerimaan HAM dapat dipijakkan kepada ayatayat al-Qur'ān, namun dapat dipastikan penolakan terhadapnya juga tetap tidak bisa dihentikan. Perkembangan sejumlah diskursus HAM, seperti LGBT, KBB dan pernikahan beda agama, senantiasa akan tetap terbagi ke dalam dua pandangan tersebut. Perkiraan ini didasarkan pada proses demokratisasi transisional yang sedang berjalan di Indonesia. Pada tahapan kedua dalam demokrasi ini pelbagai elemen masyarakat memperoleh kebebasan untuk mengartikulasikan pendapatnya, sekalipun berbeda dengan negara dan kelompok lain.

Karena itu, yang penting dalam menyikapi pertentangan ini adalah melakukan tindakan semasif mungkin dalam menyosialisasikan berbagai titik perjumpaan antara HAM dan sharíah. Perbedaan wacana tersebut tidak berakibat pada terjadinya praktik anarkis seperti yang marak belakangan ini. Meskipun keragaman wacana tidak mungkin bisa dihindarkan, tidak berarti pengembangan wacana yang lebih afirmatif terhadap HAM tidak bisa dilakukan. Cara yang bisa ditempuh antara lain dengan memanfatkan institusi pendidikan umat 
Islam seperti yang dimiliki oleh Muhammadiyah dan Nahdlatul Ulama untuk mempromosikan HAM.

\section{Daftar Rujukan}

'Abduh, Muhammad dan Riḍā, Muhammad Rashīd. Tafsir al-Mannār, Vol. 6. Beirut: Dār al-Ma'rifah, t.th.

Abu-Nimer, Mohammed. Nonviolance and Peace Building in Islam: Theory and Practice. Florida, University Press of Florida: 2003.

Akbarzadeh, Shahram dan MacQueen, Benjamin. "Framing the Debate on Islam and Human Rights", dalam Shahram Akbarzadeh dan Benjamin MacQueen (eds.). Islam and Human Rights in Practice: Perspective across the Ummah. London: Routladge, 2008.

al-Jabiri, Muhammad Abid. Syura Tradisi Partikularitas Universalitas, terj. Mujiburrahman. Yogyakarta: LKiS, 2003.

An-Na'im, Abdullah Ahmed. Islam and the Secular State: Negotiating the Future of Syariah. Massachusetts: Harvard University Press, 2008. an-Na'im, Abdullahi Ahmed. Dekonstruksi Syari'ab: Wacana Kebebasan Sipil, Hak Asasi Manusia dan Hubungan Internasional dalam Islam, terj. Ahmad Suaedy dan Amirudin ar-Rany. Yogyakarta: LKiS, 2001.

Arifin, Syamsul. "Indonesian Discourse on Human Rights and

Religious Freedom: Muslim Perspective", Brigham Young University Law Review, Vol. 2012.

-----. Attitudes to Human Rights and Freedom of Religion or Belief in Indonesia: Voices of Islamic Religious Leaders in East Java. Yogyakarta: Kanisius, 2010.

Asplund, Knut D., Marzuki, Suparman., dan Riyadi, Eko (eds.). Hukum Hak Asasi Manusia. Yogyakarta, PUSHAM UII: 2008.

Baderin, Mashood A. Hukum Internasional Hak Asasi Manusia dan Hukum Islam. Jakarta: Komnas HAM RI, 2010.

Eltayeb, S.M. "A Human Rights Framework for Defining and Understanding Intra-Religious Persecution in Muslim Countries", dalam Nazila Ghanea (ed.), The Challenge of Religious Discrimination at the Dawn of the Millenium. Leiden: Martinus Nijhoff Publisher, 2003.

https://www.republika.co.id/berita/nasional/umum/16/03/03/o3g qlz361-ini-kata-quraish-shihab-soal-kaum-lgbt. (dikutip dari Republika.co (Selasa, 16/10/2017)

Hafiz, Muhammad. "Dinamika Hukum dan Hak Asasi Manusia di Negara-negara Muslim”, Jurnal al-Ahkam, Vol. 23 No. 2, 2013. 
Hidayati, Wahyu. Apakah Kebebasan Beragama: Bebas Pindah Agama? Perspektif Hukum Islam dan HAM. Salatiga: STAIN Salatiga Press, 2008.

Imam, Ibrahim. "Shariah and Human Rights Perspective on Interfaith Marriage: Challenges Impeding its Practice in Nigeria" Islam and Civilisational Renewal Journal, Vol. 7, No. 4, 2016.

Jazāirī (al), 'Abd al-Raḥmān. Kitāb al-Fiqh al al-Madhähib al-Arba'ah, Vol. 5. Beirut: Dār al-Fikr al-'Arabī, t.th.

Kamali, Mohammad Hashim. An Introduction to Shariah. Selangor: Ilmiah Publisher, 2006.

Kamruzzaman, Md. "Interreligious Marriage in Bangladesh: From Human Rights", International Journal of Education, Culture and Society, Vol. 1, No. 2, September, 2016.

Kuntowijoyo. Paradigma Islam: Intrepretasi untuk Aksi. Jakarta: Mizan, 1991.

Muedini, Fait A. "Eximining Islam and Human Rights from the Perspective of Sufism", Muslim World Journal of Human Rights, Vol. 7, No. 1, 2010.

Mutahhari, Murtadha. Manusia dan Agama. Bandung, Mizan: 1984.

Muwaffiq, Jufri. "Pembatasan Terhadap Hak dan Kebebasan Beragama di Indonesia", Jurnal Ilmiah Pendidikan Pancasila dan Kewarganegaraan, Vol. 1, No. 1, Juni, 2016.

Rangkuti, Ramlan Yusuf. "Homoseksual dalam Perspektif Hukum Islam”, Jurnal Asy-Syir'ah, Vol. 46, No. 1, Januari-Juni 2012.

Rompis, Debora Aprilany Grace. "Praktik Ratifikasi terhadap Perjanjian Internasional Hak Asasi Manusia di Indonesia", Jurnal ex Crimen, Vol. 6, No. 4, Juni, 2017.

Runzo, Joseph., Martin, Nancy M., and Sharma, Arvind. "Introduction,", dalam Joseph Runzo, Nancy M. (eds.), Human Rights and Responsibilities in the Modern Religions. Oxford: Oneworld Publications, 2003.

Salim, Arskal dan Azra, Azyumardi. "Introduction: The State and Shari'a in The Perspective of Indonesia Legal Politics", dalam Azyumardi Azra dan Arskal Salim (eds.), Shariah and Politics in Modern Indonesia. Singapore: Institute of Southeast Asian Studies, 2003.

Shātịīi (al), Abū Isḥāq. al-Muwāafaqāt fì Ușūl al-Sharīah, Vol. 2. Beirut: Dār al-Kutub al- 'Ilmìyah: t.th. 
Sirry, Mun'im (ed.). Fiqih Lintas Agama: Membangun Masyarakat InklusifPluralis. Jakarta: Yayasan Waqaf Universitas Paramadina, 2003.

Syafi'ie, M. "Ambiguitas Hak Kebebasan Beragama di Indonesia dan Posisinya Pasca Putusan Mahkamah Konstitusi”, Jurnal Konstitusi, Vol. 5, No. 8, Oktober, 2011.

Ṭabarī (al), Abū Ja'far Muhammad b. Jarīr. Jämi' al-Bayān 'an Ta'wūl Ay al-Qur'ān, dikomentari Șidqī Jāmil al-Aț̣ār, Vol. 2 Beirut: Dār alFikr, 2001.

Tibi, Bassam. "Islamic Law/Shari'a, Human Rights, Universal Morality and International Relations", 16 Human Rights Quarterly, Vol. 16, No. 2, 1994.

Twiss, Sumner B. "History, Human Rights and Globalization", The Journal of Religious Ethics, Vol. 32, No. 1, Spring, 2004.

Zuhdi, Masjfuk. Masail Fiqhiyah. Jakarta: Karya Unipress, 1988. 